\title{
KONTRIBUSI PEKERJAAN SAMPINGAN PETANI TERHADAP EKONOMI RUMAH TANGGA DI DESA PAKONG KECEMATAN PAKONG, PAMEKASAN
}

\author{
Mohammad Shoimus Sholeh $^{1}$ *, Luluk Mublihatin ${ }^{2)}$ \\ 1)*,2) Fakultas Pertanian Universitas Islam Madura, email: moh.shoimus@gmail.com \\ 2) Fakultas Pertanian Universitas Islam Madura, email: luluk040597@gmail.com \\ email : $\underline{\text { moh.shoimus@gmail.com }}^{1)^{*}}, \underline{\text { luluk040597@gmail.com }}{ }^{2)}$
}

\begin{abstract}
ABSTRAK
Petani di Desa Pakong mayoritas tidak hanya mengandalkan hasil usahatani dalam memenuhi kebutuhan sehari-hari akan tetapi juga melakukan pekerjaan sampingan untuk menambah pendapatan total keluarga. Makadari itu perlu dikaji besaran kontribusi pendapatan petani terhadap pendapatan rumah tangga. Total pendapatan rumah tangga petani di Desa Pakong sebesar Rp.2.205.497,-/bulan dan pendapatan Rata-rata pekerja sampingan sebesar Rp. 641,667,-/bulan. Sehingga Rata-rata kontribusi pekerja sampingan terhadap pendapatan petani di Desa Pakong sebesar 29,09\%. Hal ini menunjukkan bahwa kontribusi pendapatan usahatani padi lebih besar dibandingkan kontribusi pendapatan dari pekerjaan sampingan. Meskipun kontribusinya masuk kategori kecil disarankan agar petani tetap melakukan pekerjaan sampingan untuk menambah pendapatan ekonomi rumah tangga.
\end{abstract}

Kata kunci: Kontribusi, Pekerjaan Sampingan, Pendapatan.

\section{PENDAHULUAN}

Sektor pertanian memegang peranan penting dalam pembangunan. Peran penting sektor pertanian tersebut menjadikan pembangunan pertanian sebagai prioritas dalam setiap langkah pembangunan (Mulyaningsih et al., 2018). Sektor pertanian masih menjadi andalan penciptaan lapangan pekerjaan dalam jumlah yang cukup besar, di mana dari tahun 2005 sampai tahun 2015 rata-rata $40 \%$ dari total angkatan kerja bekerja di sektor pertanian (Badan Pusat Statistik, 2018).

Pekerjaan sampingan merupakan pekerjaan tambahan yang dimiliki seseorang, biasanya pekerjaan ini ada dikarenakan pendapatan yang diperoleh dari pekerjaan pokok belum mencukupi untuk memenuhi kebutuhan pokok sehari-hari. Pekerjaan sampingan adalah suatu usaha atau pekerjaan yang dikerjakan oleh seseorang di luar pekerjaan aslinya yang selama ini telah digeluti dan dikerjakan. Misalnya pekerjaan tetapnya adalah petani, dan jenis pekerjaan sampingan nya adalah jual pulsa atau jadi kuli bangunan dan lain sebagainya (Rozali, 2018).

Rumah tangga miskin di desa memiliki tingkat ketergantungan lebih tinggi pada pertanian, karena sektor perekonomian yang bukan berasal dari pertanian tidak dapat berkembang di bidang produksi usaha kecil atau kebutuhan sehari hari. Sedangkan terjadi adanya penurunan tajam dalam hasil produktivitas panen dari hampir seluruh jenis hasil pertanian, ditambah mayoritas petani yang bekerja di sawah kurang dari setengah hektar, aktivitas pertanian kehilangan potensi untuk menciptakan tambahan lapangan pekerjaan dan peningkatan penghasilan sehingga petani memerlukan pendapatan 
tambahan untuk kebutuhan sehari hari.

Seperti halnya di Desa Pakong Kecamatan Pakong Kabupaten Pamekasan yang mayoritas masyarakat nya dalam kehidupan sehari hari masih mengandalkan hasil pertanian, pertanian di desa menjadi mata pencaharian yang masih banyak di geluti oleh masyarakat pakong, meskipun kenyataanya masyarakat pakong banyak yang tidak terpenuhi kebutuhannya dikarenakan kebutuhan ekonomi keluarga semakin banyak, harga harga kebutuhan yang semakin meningkat dan pendapatan keluarga yang cenderung tidak bertambah sedangkan hasil pertanian tidak cukup untuk memenuhi kebutuhan pokok para petani. Menurut Mubyarto (1992) pendapatan rumah tangga diartikan sebagai pendapatan yang diperoleh seluruh anggota keluarga, baik suami, istri, maupun anak.

Oleh karena itu Petani di Desa Pakong dalam memenuhi kebutuhan ekonomi rumah tangga selain mengandalkan hasil pertanian, mereka mempunyai strategi yaitu dengan melakukan pekerjaan sampingan yang terdiri dari peternak (ternak sapi, ayam dan kambing), pedagang (warung, pedagang kaki lima), buruh (buruh tani), yang terakhir adalah jasa. Sehingga petani di Desa Pakong tidak hanya mendapatkan pendapatan dari hasil pertanian akan tetapi juga adanya kontribusi pekerja sampingan terhadap ekonomi rumah tangga dan stabilitas perekonomian keluarga petani di Desa Pakong tidak terganggu.

Berdasarkan latar belakang tersebut maka perlu dikaji terkait dengan kontribusi pekerja sampingan petani terhadap ekonomi rumah tangga di Desa Pakong Kecematan Pakong Kabupaten Pamekasan.

\section{METODE PENELITIAN}

Sampel dalam penelitian ini sebanyak 34 petani yang memiliki pekerjaan sampingan. Analisis ini digunakan untuk mengetahui kontribusi pendapatan pekerja samping terhandap pendapatan total rumah tangga petani dalam satuan persen. Kontribusi adalah sumbangan yang dapat diberikan oleh suatu hal terhadap hal lain. Data yang diperoleh dianalisis tanpa uji statistik dengan menghitung jumlah uang yang diperoleh dari pekerja sampingan dan pendapatan total rumah tangga petani dikali seratus persen. Untuk mengetahui kontribusi pendapatanpekerjaan sampingan terhadap pendapatan total rumah tangga digunakan rumus persentase sebagai berikut:

Kontribusi $=$

$\frac{\text { Pendapatan sampingan }}{\text { Total pendapatan keluarga }} \times 100 \%$

Menurut Samadi (2001), untuk menetapkan besar kecilnya kontribusi Pendapatan pekerjaan sampingan terhadap total pendapatan keluarga, maka diukur dengan:

1. Jika kontribusi $<50 \%$, maka kontribusi kecil.

2. Jika kontribusi $=50 \%$, maka kontribusi sedang.

3. Jika kontribusi $>50 \%$, maka kontribusi besar.

\section{HASIL DAN PEMBAHASAN}

\subsection{Analisis Usahatani}

Analisis usahatani merupakan metode analisis untuk mengukur kelayakan usaha. Hasil analisis usahatani padi sawah (Oryza sativa.L) di Desa Pakong disajikan pada Tabel 1.

Tabel 1. Analisis Usahatani

\begin{tabular}{lr}
\hline \multicolumn{1}{c}{ Jenis } & \multicolumn{1}{c}{ Biaya (Rp) } \\
\hline Fix cost & $1.487 .999,00$ \\
Variable cost & $1.070 .000,00$ \\
Total cost & $2.557 .999,00$ \\
Hasil Produksi (Y) & $2203,33 \mathrm{~kg}$ \\
Harga (Py) & Rp. 4000,00 \\
Penerimaan & Rp. $8.813 .320,00$
\end{tabular}


Keuntungan

6.255.321,00/musim $1.563 .830,00 / \mathrm{bln}$

Sumber : Data primer yang diolah, 2020

Berdasarkan Tabel 1. rata-rata keuntungan yang diterima petani dari usahatani padi sebesar Rp 1.563.830,00/bulan. Hal ini menandakan bahwasanya keuntungan yang di dapat terbilang sedikit jika melihat keadaan kebutuhan petani di Desa Pakong, sehingga para petani di sana menambah pekerjaan mereka agar pendapatannya bertambah dan mampu memenuhi kebutuhan para petani.

\section{Kontribusi Pendapatan Pekerjaan Sampingan Petani}

Mayoritas petani di Desa Pakong mengelola lahan pertaniannya untuk usahatani tanaman semusim. Jika saat musim penghujan mayotitas lahan digunakan untuk budidaya tanaman padi. Melihat wilayah Desa Pakong termasuk pedesaan dan masyarakat banyak bertani, maka kebutuhan hidup bergantung dari besarnya kontribusi hasil tani disamping juga menambah penghasilan dari pekerjaan sampingan.

Berdasarkan mata pencahariannya selain menjadi petani maka penduduk Desa Pakong dapat dibedakan menjadi beberapa sumber mata pencaharian seperti Pedagang, Pembajak, Wiraswasta, Guru, Kuli Bangunan, Buruh Kerja dan lain-lainnya. Sehingga dapat diketahui dari pekerjaan sampingannya rata-rata pendapatan responden sebanyak Rp.641.667.

Kontribusi adalah sumbangan yang dapat diberikan oleh suatu hal terhadap hal lain. Data yang diperoleh dianalisis tanpa uji statistik dengan menghitung jumlah uang yang diperoleh dari pekerjaan sampingan dibagi pendapatan total rumah tangga petani dikali seratus persen. Sedangkan pendapatan total rumah tangga di peroleh dari pendapatan usahatani ditambah pendapatan pekerjaan sampingan. Untuk mengetahui kontribusi pendapatan pekerjaan sampingan terhadap pendapatan total rumah tangga disajikan pada Tabel 2.

Tabel 1. Kontribusi Usahatani

\begin{tabular}{lr}
\hline \multicolumn{1}{c}{ Jenis } & \multicolumn{1}{c}{ Biaya (Rp) } \\
\hline Pendapatan usahatani & $1.563 .830,00$ \\
Pendapatan sampingan & $641.667,00$ \\
Todal Pendapatan & $2.205 .497,00$ \\
Kontribusi $(\%)$ & $29,09 \%$ \\
\hline
\end{tabular}

Sumber : Data primer yang diolah, 2020

Berdasarkan hasil penghitungan diatas total pendapatan rumah tangga petani di Desa Pakong sebesar Rp.2.205.497,-/bulan dan pendapatan Rata-rata pekerja sampingan sebesar Rp. 641,667,-/bulan. Sehingga Ratarata kontribusi pekerja sampingan terhadap pendapatan petani di Desa Pakong sebesar 29,09\%. Hal ini menunjukkan bahwa kontribusi pendapatan usahatani padi lebih besar dibandingkan kontribusi pendapatan dari pekerjaan sampingan.

Selaras dengan hasil penelitian Zuhurony et al., (2020) menunjukkan kontribusi pendapatan usahatani padi terhadap pendapatan rumah tangga petani di Kota Mojokerto sebesar 67,26\%. Sejalan dengan hasil penelitian Harviani et al., (2019) menunjukkan bahwa pendapatan yang diterima petani dari usahatani padi di Kecamatan Demak Kabupaten Demak sebesar Rp. 3.612.265,-/bulan dan kontribusinya terhadap pendapatan total rumah tangga petani sebesar $65 \%$.

Penelitian Maluhima et al., (2020) menunjukkan bahwa pendapatan usahatani padi sawah dapat memberikan kontribusi sebesar 53\% dengan pendapatan usahatani perbulannya sebesar Rp.2.967.050,-.

Rata-rata nilai kontribusi usahatani padi dengan luasan yang berbeda dari beberapa hasil penelitian lebih dari 50\%, artinya petani bergantung dari hari usahatani padi untuk memenuhi segala kebutuhan 
sehari-hari dari pada mengandalkan pekerjaan sampingan. Umumya pekerjaan sampingan yang dilakukan petani seperti berdagang atau kuli (tukang bangunan).

Syamsiah et al.,(2017) menghitung besaran kontribusi pendapatan usahatani padi bervariasi mulai $12 \%$ hingga $100 \%$ dengan rata-rata kontribusi $68,88 \%$. Sejalan hasil penelitian Pratiwi et al., (2018) kontribusi pendapatan usahatani padi terhadap pendapatan rumah tangga di Desa Sambeng Kulon Kecamatan Kembaran sebesar $54,96 \%$.

Responden dalam penelitian ini melakukan pekerjaan sampingan dan tetap melakukan usaha tani Karena kegiatan kegiatan usaha tani merupakan kegiatan skala kecil dan tidak terlalu membutuhkan waktu yang lama sehingga mereka melakukan pekerjaan lain untuk mengisi waktu dan juga untuk menambah pendapatan untuk keluarga. KESIMPULAN

Total pendapatan rumah tangga petani di Desa Pakong sebesar Rp.2.205.497,-/bulan dan pendapatan Rata-rata pekerja sampingan sebesar Rp. 641,667,-/bulan. Sehingga Ratarata kontribusi pekerja sampingan terhadap pendapatan petani di Desa Pakong sebesar 29,09\%. Hal ini menunjukkan bahwa kontribusi pendapatan usahatani padi lebih besar dibandingkan kontribusi pendapatan dari pekerjaan sampingan. Meskipun kontribusinya masuk kategori kecil disarankan agar petani tetap melakukan pekerjaan sampingan untuk menambah pendapatan ekonomi rumah tangga.

\section{DAFTAR PUSTAKA}

Badan Pusat Statistik. 2018. Pendataan Sosial Ekonomi. Badan Pusat Statistik. Jakarta.

Harviani, B. D., Prasetyo, E. dan Setiawan, B. M. 2019. Kontribusi Pendapatan Usahatani Padi Terhadap Pendapatan Total Rumah Tangga Pada Petani
Anggota Gapoktan Tani Makmur Kecamatan Demak Kabupaten Demak. Jurnal Sungkai, 7(2): 74-80.

Maluhima, S., Memah, M. Y. dan Sendow, M. M. 2020. Kontribusi Usahatani Padi Sawah Terhadap Pendapatan Keluarga Petani di Desa Amongena II Kecamatan Langowan Timur, Minahasa. AGRIRUD, 1(4): 515-523.

Mubyarto. 1992. Tanah dan Tenaga kerja: (Kajian Sosial Ekonomi). Aditya Media. Yogyakarta.

Mulyaningsih, A., S Hubeis, A. V., Sadono, D. dan Susanto, D. 2018. Partisipasi Petani pada Usahatani Padi, Jagung, dan Kedelai Perspektif Gender. Jurnal Penyuluhan, 14(1): 145-158.

Pratiwi, C. A., gunawan, D. S. dan istiqomah. 2018. Analisis Ekonomi Usahatani Padi Dan Kelayakan Rumah Tangga Tani di Desa Sambeng Kulon Kecamatan Kembaran Kabupaten Banyumas. JSEP,11(1): 33-45.

Rozali, A. (2018). Karakteristik Sosial Ekonomi Keluarga Buruh CV Bumi Indah Kelurahan Garuntang Kecamatan Bumi Waras Kota Bandar Lampung Tahun 2018. Universitas Lampung.

Samadi, Budi. 2001. Kinerja Tenaga Kerja Wanita. Yogyakarta: Graha Ilmu.

Syamsiyah, N., Thoriq, A., Pardian, P., Karyani, T. dan Kusno, K. 2017. Tingkat Pendapatan Usahatani Padi dan Kontribusinya Terhadap Pendapatan Petani. Jurnal Agribisnis Terpadu, 10(1): 76-87.

Zuhurony1, H. dan Susilowati, D. 2020. Analisis Kontribusi Usahatani Padi Terhadap Pendapatan Rumah Tangga Petani Padi di Lingkungan Sekarputih Kota Mojokerto Jawa Timur. Jurnal Ketahanan Pangan, 4(1): 17-27. 